\title{
The wood-destroying fungi in buildings in Estonia
}

\author{
K. Pilt ${ }^{1}$, J. Oja ${ }^{2} \&$ K. Pau ${ }^{3}$ \\ ${ }^{I}$ Department of Rural Building, Estonian University of Life Sciences, \\ Estonia \\ ${ }^{2}$ Department of Botany, University of Tartu, Estonia \\ ${ }^{3}$ Estonian Mycology Research Centre, Estonia
}

\begin{abstract}
From 2002 until the end of 2008, 633 private and public buildings damaged by wood-destroying fungi were inspected in Estonia. Most of the inspections have been carried out in Tallinn - $101(16 \%)$ and Tartu - $89(14 \%)$, and also in the counties around these cities - Harju and Tartu Counties. The analysis revealed that the true dry rot fungus, Serpula lacrymans, was the most common fungus (79\%) in buildings all over Estonia. The next most frequent fungi were Coniophora puteana (7\%) and different species of the family Corticiaceae (4\%). The Estonian data were compared to the results of Finnish, Latvian and Norwegian studies. Occurrences of wood-destroying fungi correlated with the monthly mean temperatures while there was no correlation with mean relative humidity.
\end{abstract}

Keywords: cultural heritage, dry rot, wood-destroying fungi, Serpula lacrymans, Coniophora puteana.

\section{Introduction}

Over the last century there has been at least one period of high activity of wooddestroying fungi and insects in Estonia. After World War II, lots of buildings, including cultural monuments, had to be renovated and refurbished. Since substandard building materials, including timber, often with an inadequately high moisture content were used, the wood-destroying fungi easily spread all over Estonia. The aftermath of that period lasted until the mid-1960s [1]. Research on 
wood-destroying fungi has established a clear-cut relationship between the rate of wood deterioration and the age of wood in the building. In many buildings slightly damaged old elements were, and are, replaced by new elements of the same size and shape, whereby the growth of destroying fungi is further enhanced as the spread rate in fresh cut timber is manifold higher than in the old one [2].

In 2008 there were 26,028 officially registered cultural heritage items in Estonia, including historical, archaeological, architectural, artistic, and industrial monuments [3]. The majority of the items are artistic monuments that are deposited in and protected by museums and arts depositories, among which the KUMU Art Museum is the largest. While the depositories have the facilities to maintain appropriate conservation conditions and major problems with biodeterioration can be prevented, the items of architectural monuments $(5,277$ in total) run the highest risk of bio-deterioration.

Bio-deterioration of building materials may be caused by several biological agents like bacteria, insects, lichens, algae, mosses, rodents, mammals, birds, higher plants and fungi [4].

In this paper only the bio-deterioration of timber caused by fungi is analysed although the other agents have been noticed too. The fungal attack can be caused either by wood-destroying fungi or by wood-disfiguring fungi, for example blue stain and mould fungi [5]. The indoor wood-destroying fungi cause considerable damage to the interior structural timber [6]. The most frequently recorded wooddegrading fungi within buildings in Europe and North America are fungi that cause brown-rot in conifers while white-rot fungi, which preferentially attack hardwoods, are less common in buildings [4]. The true dry rot fungus, Serpula lacymans, is one of the most destructive and least controllable fungi causing timber decay in Europe [7]. It is capable of spreading across the house in a very short period of time (a couple of years) causing enormous material losses [8]. Building defects and failures often lead to the development of fungi and (biological) decay problems [4].

Nowadays, building techniques, new construction materials, short construction time and few qualified engineers have given a severe increase in fungal damaged buildings in Estonia [9]. Main building defects in Estonia are: improper use of building materials, inefficient ventilation system, inadequate performance of roof and rainwater runoff, damaged drainpipes and water-pipes, changes in the floor structures during renovation, and changes in the function of buildings and rooms. Often damp rooms (bathrooms, saunas, pools, etc.) are built in old-age buildings the original design of which did not feature these facilities. As can be seen from these cases, a favourable microclimate for the development of fungus is mainly created by the human activity or inactivity.

The aim of this paper is to analyse the diversity of wood-destroying fungi in Estonian buildings and to compare the database with other published studies from close regions. The dependence of occurrence of wood-destroying fungi on the climate conditions, and the regional and seasonal distribution of cases where wood-destroying fungi was found were examined as well. 


\section{Material and methods}

The data for this analysis have been collected by Estonian Mycology Research Centre (EMRC). Foundation EMRC was established in 2002 with purposes to provide expertise in building mycology and to raise public awareness in maintenance of buildings through trainings, popular scientific papers, and information across multi-media channels. During a period of 7 years (20022008) altogether 993 private and public buildings with fungal damages were inspected on the bases of callouts. Inspected buildings are located in different areas of Estonia.

By the first decade of independence, most of the old buildings had been returned to their previous owners. At the Soviet time there was lack of knowledge about wood-destroying fungi and also lack of qualified specialists in Estonia. At the same time little attention was paid to the maintenance of buildings and the houses needed thorough repairs. New owners made several mistakes while renovating their property and moisture pattern changes led to the development of fungi. The demand for the consultation evolved.

In the course of inspections the samples of fungi were collected along with a piece of wood or removed from surfaces by scalpel and stored in the envelope until laboratory analyses. The moisture content of the materials was measured and closed structures investigated to determine the extent and type of the damage.

Wood-destroying fungi were identified by the morphology of fruiting bodies and strands using light microscopy and reagents $(3 \% \mathrm{KOH}$, cotton blue). Wooddestroying fungi were identified according to the keys by Hallenberg 1985 [10], Bech-Andersen [11], Huckfeldt and Schmidt [12], and Niemelä [13]. Besides, some certain characteristics were included in the identification: appearance of decayed wood, the moisture content of the materials and location of sample.

The European Standard EN 335-1 [5] was used to categorise the inspected cases. In 633 cases the buildings were damaged by wood-destroying fungi while in 360 cases wood-disfiguring fungi were identified. Only the cases of wooddestroying fungi were included in the analysis and out of 633 analysed cases 22 are architectural monuments.

Since in less than $95 \%$ of cases one survey revealed more than one species of fungi only the main wood-destroying fungi were included in to the database analysed in this paper.

The relative air humidity in the buildings and the absolute moisture content of the materials were determined with Protimeter Moisture Measurement System and GANN Electronic Moisture Meter Hydromette UNI 2. The surveys on enclosed structures were performed with Olympus Fibreoptic device R080-063045SW115-50.

All meteorological data concerning the relative air humidity and temperature was gathered by Estonian Meteorological and Hydrological Institute (EMHI) and was given as the average of the month or season.

The correlation between climate and number in a number of cases was analysed with the statistical program $\mathrm{R}$ (version 2.8.1). 
Table 1: $\quad$ Wood-destroying fungi identified in Estonian buildings.

\begin{tabular}{|c|c|c|c|c|c|c|c|c|c|}
\hline Fungal species & 2002 & 2003 & 2004 & 2005 & 2006 & 2007 & 2008 & $\begin{array}{l}\text { No of } \\
\text { cases }\end{array}$ & $\begin{array}{c}\% \\
\text { from } \\
\text { cases }\end{array}$ \\
\hline Antrodia spp.: & & & 4 & 3 & 6 & 10 & 11 & 34 & 5.3 \\
\hline Antrodia sp. & & & 1 & & & 2 & 1 & 4 & 0.6 \\
\hline Antrodia serialis & & & & 1 & 1 & 1 & 7 & 10 & 1.6 \\
\hline Antrodia sinuosa & & & 3 & & 3 & 4 & 1 & 11 & 1.7 \\
\hline Antrodia vaillantii & & & & 2 & 2 & 3 & 2 & 9 & 1.4 \\
\hline $\begin{array}{l}\text { Coniophora } \\
\text { marmorata }\end{array}$ & & & 1 & & & & 1 & 2 & 0.3 \\
\hline Coniophora puteana & & & 8 & 7 & 15 & 6 & 8 & 44 & 7.0 \\
\hline $\begin{array}{l}\text { Cylindrobasidium } \\
\text { evolvens }\end{array}$ & & & & & 1 & & & 1 & 0.2 \\
\hline Fomitopsis pinicola & & & & 1 & & & & 1 & 0.2 \\
\hline Hyphodontia sp. & & & & & & 1 & & 1 & 0.2 \\
\hline $\begin{array}{l}\text { Leucogyrophana } \\
\text { pulverulenta }\end{array}$ & & 2 & 6 & 7 & 1 & 0 & 3 & 19 & 3.0 \\
\hline Paxillus panuoides & & 1 & & 1 & & & 1 & 3 & 0.5 \\
\hline Phlebiopsis gigantea & & & & 1 & & & & 1 & 0.2 \\
\hline Serpula himantioides & 1 & & & & & & & 1 & 0.2 \\
\hline $\begin{array}{l}\text { Serpula lacrymans } \\
\text { Unidentified }\end{array}$ & 21 & 32 & 80 & 56 & 83 & 107 & 123 & 502 & 79.3 \\
\hline Corticiaceae s. lat. & & & 2 & 3 & 6 & 7 & 5 & 23 & 3.6 \\
\hline $\begin{array}{l}\text { Unidentified } \\
\text { Polyporaceae s. lat. }\end{array}$ & & & & & & 1 & & 1 & 0.2 \\
\hline Total & 22 & 35 & 101 & 79 & 112 & 132 & 152 & 633 & 100 \\
\hline
\end{tabular}

\section{Results and discussion}

\subsection{Occurrence of wood-destroying fungal species in buildings}

There were altogether 16 different species, genera or families of wooddestroying fungi found from the investigated buildings in Estonia, table 1.

Brown-rot fungi were the predominantly found fungi, while few white rot fungi were identified. The true dry rot fungus (Serpula lacrymans) was the most common species. It was found in 502 cases, i.e. $79.3 \%$ of all the analysed samples. One reason for the high percentage of Serpula lacrymans is the wide use of coniferous (pine and spruce) timber and limestone or other calcium-rich stone materials together. During the growth the true dry rot fungus produces strong acid which can kill the fungus itself if there is no calcium for the neutralisation of the oxalic acid [11]. On the other hand it should be noted that building investigations were carried out on the bases callouts. The damages caused by Serpula lacrymans are easily visible to the customers since the 
appearance of red coloured spore dust and fast degradation of wood. The second most frequently identified fungus was the cellar fungus, Coniophora puteana $(7.0 \%)$ and the third most often found fungi belong to the family Antrodia spp. (5.3\%). The species of Antrodia were identified in most of the cases to the species level but to make the comparison with other studies easier the cases were counted together. Species of Corticiaceae were identified only to family level since their fruiting bodies are thin (a few mm thick) and tightly appressed to the substrate what makes the removing the fruiting bodies for microscopy analysis hard.

In addition to the most frequently identified fungi in 3\% of the cases the damages by Leucogyrophana pulverulenta were identified. Surprisingly in 2005 the red banded polypore fungus (Fomitopsis pinicola), which usually grows on coniferous and deciduous logs and stumps causing brown rot was found inside the building. Besides the aforementioned rot causing fungal species, the fungal species common in nature, like cup-fungi (species) and the ink caps (Coprinus species) were found from buildings. These species however were not analysed in this paper since they do not belong to wood-destroying fungi according to the European Standard EN 335-1 [5].

Compared to the studies from Norway [14], Finland [15] and Latvia [16] some differences were found from Estonian results.

Table 2: $\quad$ The most frequent wood-destroying fungi in Estonia, Latvia [16], Norway [14], and Finland [15].

\begin{tabular}{|c|c|c|c|c|c|}
\hline & \multirow{2}{*}{$\begin{array}{l}\text { Estonia } \\
\text { 2002-08 }\end{array}$} & \multirow{2}{*}{$\begin{array}{c}\text { Latvia } \\
\text { 1996-2007 }\end{array}$} & \multirow{2}{*}{$\begin{array}{l}\text { Norway } \\
2001-03\end{array}$} & \multicolumn{2}{|c|}{ Finland } \\
\hline & & & & $1978-84$ & $1985-88$ \\
\hline 1. & $\begin{array}{l}\text { Serpula } \\
\text { lacrymans } \\
79 \%\end{array}$ & \begin{tabular}{|l} 
Serpula \\
lacrymans \\
$47 \%$
\end{tabular} & $\begin{array}{l}\text { Antrodia spp. } \\
18 \%\end{array}$ & $\begin{array}{l}\text { Serpula } \\
\text { lacrymans } \\
59 \% \\
\end{array}$ & \begin{tabular}{|l} 
Serpula \\
lacrymans \\
$43 \%$
\end{tabular} \\
\hline 2. & \begin{tabular}{|l} 
Coniophora \\
puteana \\
$7 \%$ \\
\end{tabular} & $\begin{array}{l}\text { Antrodia spp. } \\
13 \%\end{array}$ & \begin{tabular}{|l} 
Coniophora \\
puteana \\
$16 \%$
\end{tabular} & \begin{tabular}{|l} 
Coniophora \\
puteana \\
$15 \%$ \\
\end{tabular} & $\begin{array}{l}\text { Antrodia spp. } \\
26 \%\end{array}$ \\
\hline 3. & $\begin{array}{l}\text { Antrodia spp. } \\
5 \%\end{array}$ & $\begin{array}{l}\text { Coniophora } \\
\text { puteana } \\
6 \% \\
\end{array}$ & \begin{tabular}{|l|} 
Serpula \\
lacrymans \\
$16 \%$
\end{tabular} & $\begin{array}{l}\text { Antrodia spp. } \\
14 \%\end{array}$ & \begin{tabular}{|l} 
Coniophora \\
puteana \\
$11 \%$
\end{tabular} \\
\hline
\end{tabular}

The data from different countries are not unconditionally comparable. First, the size of datasets is different. The Norwegian data came from 1428 consultations where 3434 occurrences of decay fungi were recorded. In Latvia 300 buildings were inspected and 338 occurrences recorded. Finnish database include 773 occurrences from samples of 661 damage cases between 1978 and 1984, and 464 occurrences from samples of 378 damage cases between 1985 and 1988. Secondly, the variability of identified fungi is different, e.g. Finnish data include mould fungi.

Most frequent fungal species in Estonia, Norway, Latvia and Finland were Serpula lacrymans, Coniophora puteana and Antrodia spp. The dominant wooddestroying fungus in Estonia, Finland and Latvia was the same - Serpula 
lacrymans, while Antrodia species were recorded as the most frequent fungi in Norway, table 2. Coniophora puteana was reported as the second frequent fungus in Finland in 1978-84 study, as well as in Estonia and Norway.

\subsection{The regional occurrence of wood-destroying fungi in Estonia}

Estonia is situated on the East cost of the Baltic Sea with the territory of 45.227 $\mathrm{km}^{2}$ and is the smallest Baltic country with population of 1.34 million (1 January 2009) [17]. Estonia is administratively divided into 15 counties. The capital city Tallinn is located in the Northern part of Estonia along the Gulf of Finland. It is the biggest city in Estonia where lives 30\% of Estonian population. The second biggest city is Tartu in the South Estonia by the river Emajõgi.

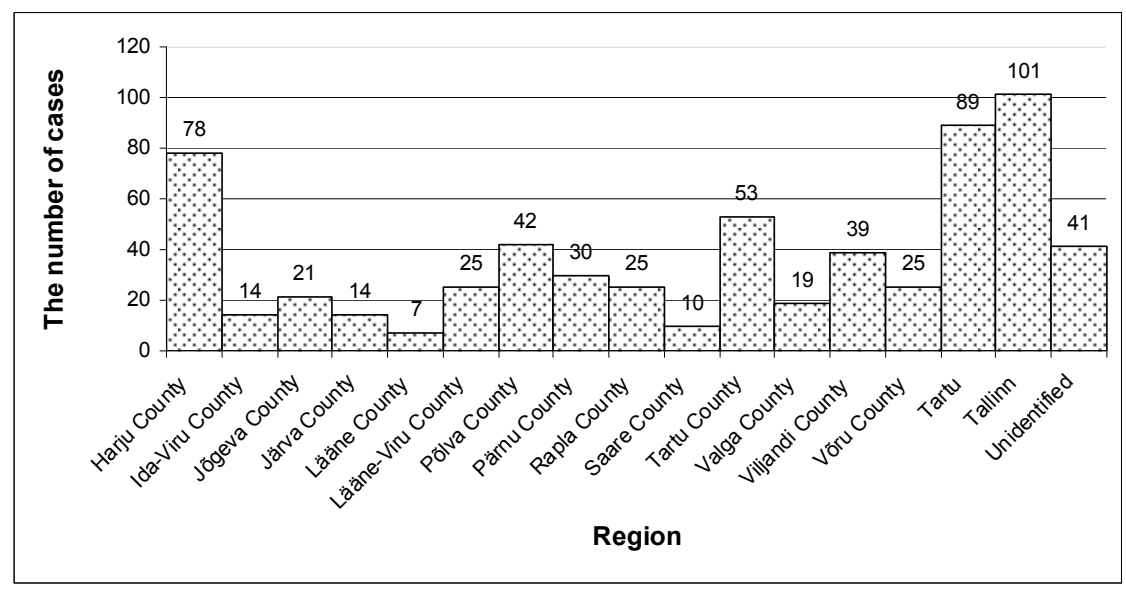

Figure 1: The regional occurrence of wood-destroying fungi in Estonia.

While analysing the number of surveys by counties, two biggest cities were added separately. Fungal occurrences in buildings were recorded in all counties of Estonia, except in Hiiu County, which is the second largest island. The biggest number of inspections was registered in Tallinn $-101(16 \%)$ and Tartu -89 $(14 \%)$, and in the counties around these cities - in Harju and Tartu Counties, fig 1. Fewest surveys were carried out in the western part of Estonia, in Lääne and Saare Counties, seven and ten cases respectively. High number of investigations was carried out in small Põlva County (South-Estonia) - 42 and in Viljandi County (Central-Estonia) - 39. Samples with unidentified location have been sent or brought to EMRC by customers and cannot be analysed at this point.

\subsection{Occurrence of wood-destroying fungi correlated to the climate}

Estonia lies in the northern part of the temperate climate zone and in the transition zone between maritime and continental climate. The annual average 
temperature in Estonia is between $4.3^{\circ} \mathrm{C}$ and $6.5^{\circ} \mathrm{C}$, being lower on the uplands and higher on the western coast of the islands. The vegetation period lasts for 180-195 days and the frost-free period 110-190 days. Estonia is located in a region of humid climate, where the amount of precipitation exceeds the total evaporation. The annual average of the relative air humidity is $80-83 \%$. It is higher in winter and at its lowest in May, being $70 \%$ on average. The annual average precipitation varies between 550 and $800 \mathrm{~mm}$. [18] Estonian phenological studies show that spring begins earlier and the mean temperature in spring has become significantly warmer while winter has become shorter. Other seasons have not undergone many significant changes [19].

During the period of 2002-2008 the biggest number of investigations was held in summers, fig. 3, with a maximum in August, likewise in Latvian data published in 2008 [16].

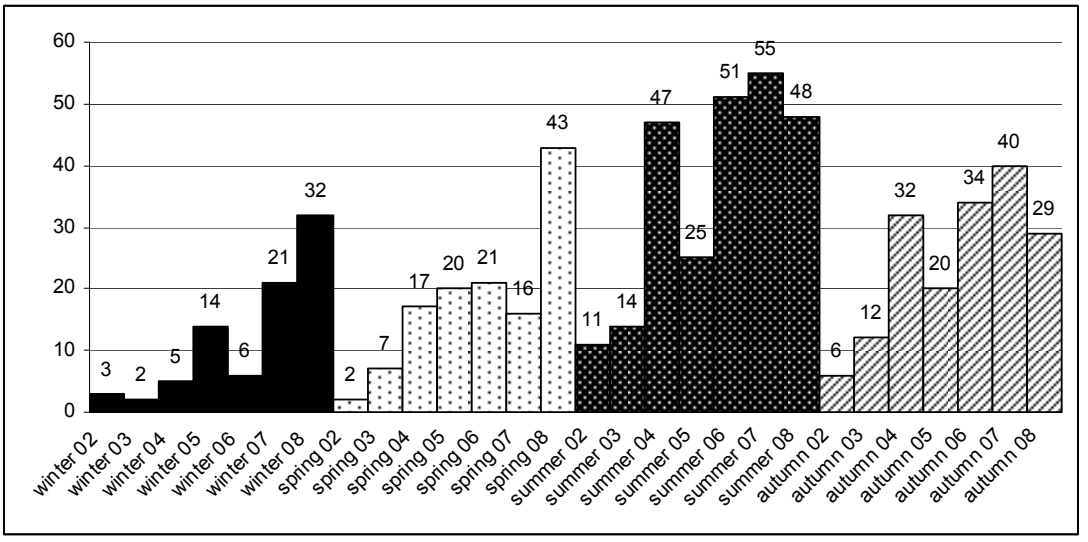

Figure 2: Distribution of investigations according to the season of the year (2002-2008).

Correlation analysis showed linear correlations between the monthly mean temperatures and number of surveys $(r=0.464, p=0.00)$, figure 4 . There was no correlation found between mean relative humidity and number of surveys.

\section{Conclusions}

The main finding of analyse was the correlation between climate and development of wood-destroying fungi. The climate influences the distribution of the most dangerous wood-destroying fungi Serpula lacrymans significantly in spite of its occurrence in Estonia indoors only.

In further studies the decay localities according to particular structural parts of buildings should be analysed and DNA-based identification techniques used of which the sequencing of the internal transcribed spacer (ITS) of the rDNA is 


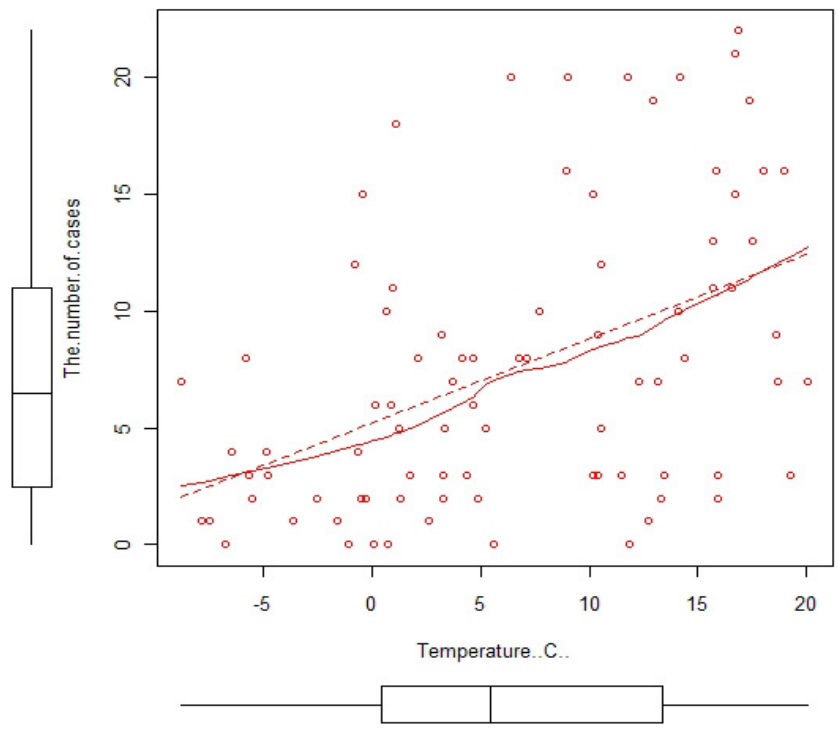

Figure 3: $\quad$ Scatter plot showing number of cases as a function of monthly mean temperature (2002-2008).

currently the best molecular tool [7]. At the very moment DNA-based identification is more expensive than light microscopy and it is the reason for not applying it in everyday inspections.

\section{Acknowledgements}

The authors would like to thank the EU COST programme for the training possibilities. We gratefully acknowledge Professor emeritus Erast Parmasto, Professor Urmas Kõljalg and Ene Indermitte for their help and support.

\section{References}

[1] Parmasto, E. Personal communication, July 2007, Extraordinary Senior Researcher, University of Tartu and Estonian University of Life Sciences, Tartu, Estonia.

[2] Pilt, K., Majaseente mõju ehitistele [The impact of fungi on buildings]. Keskkonnatehnika (in Estonian), 6, pp. 27-31, 2007.

[3] Register of Monuments; The National Heritage Board. www.muinas.ee/413

[4] Singh, J., Building Mycology. Management of decay and health in buildings, E \& FN Spon: London, 1994. 
[5] European Standard EN 335-1:1992 "Durability of wood and wood-based products - Definition of hazard classes of biological attack - Part 1: General", European Committee for Standardization: Brussels, 1992.

[6] Schmidt, O., Wood and Tree Fungi, Springer-Verlag: Berlin and Heidelberg, 2006.

[7] Schmidt, O., Indoor wood-decay basidiomycetes: damage, cause fungi, physiology, identification and characterization, prevention and control. Mycological Progress, 6, pp. 261-279, 2007.

[8] Irbe, I., Andersone, I. \& Andersons, B., Distribution of the true dry rot fungus Serpula lacrymans in Latvia. Folia Cryptogamica Estonia, 38, pp. 9-12, 2001.

[9] Täheväli-Stroh, L., Maja ja niiskus [Building and damp], Ajakirjade Kirjastus: Tallinn (in Estonian), 2005.

[10] Hallenberg, N., The Lachnocladiaceae and Coniophoraceae of North Europe, Fungiflora: Oslo, 1985.

[11] Bech-Andersen, J., The dry rot fungus and other fungi in houses, Hussvamp Laboratoriet ApS: Holte, 1995.

[12] Huckfeldt, T. \& Schmidt, O., Identification key for European strandforming house-rot fungi. Mycologist, 20, pp. 42-56, 2006.

[13] Niemelä, T., Torikseened Soomes ja Eestis [Pore Fungi in Finland and Estonia], Eesti Loodusfoto: Tartu (in Estonian), 2008.

[14] Alfredsen, G., Solheim, H. \& Jenssen, K.M., Evaluation of decay fungi in Norwegian buildings. International Research Group on Wood Protection, Section 1 Biology. 36th Annual Meeting, India: Bangalore, 24-28 April, 2005.

[15] Viitanen, H. \& Ritschkoff, A-C., Brown rot decay in wooden constructions: Effect of temperature, humidity and moisture. Report No 222. Swedish University of Agricultural Sciences, Department of Forest Products, pp. 57, 1991.

[16] Irbe, I. \& Andersone, I., Wood decay fungi in Latvian buildings including cultural monuments. International Conference on Wood Science for Preservation of Cultural Heritage: Mechanical and Biological Factors, Portugal, 2008. http://www.woodculther.com/wp-content/uploads/2009/ 03/irbe_rev1.pdf

[17] Statistics Estonia (SE), www.stat.ee

[18] Estonica; Foundation Estonian Institute. http://www.estonica.org/eng/

[19] Ahas, R. \& Aasa, A. The effects of climate change on the phenology of selected Estonian plant, bird and fish populations. International Journal of Biometeorology, 51(1), pp. 17-26, 2006. 